DOI: $10.2478 / \mathrm{v} 10025-008-0003-4$

JOURNAL OF WATER

AND LAND DEVELOPMENT

J. Water Land Dev. No. 11, 2007: 31-44

\title{
Harmonisation of water management and agricultural policies in Slovenia
}

\author{
Marina PINTAR ${ }^{1)}$, Lidija GLOBEVNIK ${ }^{2)}$, Urška BREMEC ${ }^{2)}$
}

1) Center for Agricultural Land Management and Agrohydrology, Jamnikarjeva 101, 1000 Ljubljana, Slovenia, phone: ++386 14231161; marina.pintar@bf.uni-lj.si

${ }^{2)}$ Institute for Water of Republic of Slovenia, Hajdrihova 28c, 1000 Ljubljana, Slovenia; phone: ++ 386 14775307, lidija.globevnik@guest.arnes.si, urska.bremec@izvrs.si

\begin{abstract}
In order to maintain and improve water quality, man has an increasing need to understand the relations among basin land use and in stream water quality. Being concerned about quality and quantity status of European waters European Union has adopted Water Framework Directive (2000/60/EU). The process of pressure and impact analyses and water status assessment is termed, in short, as "first characterisation" of water bodies. In accordance to WFD programmes of measures have to be developed by 2009. In WFD programmes existing measures for water protection directed by other EU directives such are Nitrate, Urban Waste Water, Dangerous Substances and IPPC will be further developed and new added. In the paper, we describe the first characterisation of the Slovene waters and show cross compliance of the Nitrate and Water Framework Directives in Slovenia.
\end{abstract}

Key words: agricultural policies, Nitrate Directive, water bodies, Water Framework Directive UE, water management

\section{INTRODUCTION}

In order to maintain and improve water quality, man has an increasing need to understand the relations among basin land use and in stream water quality. Being concerned about quality and quantity status of European waters European Union has adopted Water Framework Directive (FWD). The main aim of the mentioned directive is to reach good water status regarding quality and quantity of water by year 2015. According to FWD countries have to define water bodies characterized with the same ecological, morphological and water quality characteristics. The article 5 of the directive among others requires that each EU country will make the analysis of characteristics of watersheds and of the impacts of men's activity in them. 
Water bodies at risk should be defined as a first step. Water bodies at risk are defined as water bodies for which we are not sure that water quality will meet the requirements by year 2015. WFD demands the impacts of anthropogenic activities on the status of water bodies of surface waters and groundwater to be assessed. The process of pressure and impact analyses and water status assessment is termed, in short, as "first characterisation" of water bodies. In accordance to WFD programmes of measures have to be developed by 2009. In WFD programmes existing measures for water protection directed by other EU directives such are Nitrate, Urban Waste Water, Dangerous Substances and IPPC will be further developed and new added. In the paper, we describe the first characterisation of the Slovene waters and show cross compliance of the Nitrate and Water Framework Directives in Slovenia.

All calculations and assessments in the article based on data which have been collected for different research reports or for statistical data base. No additional physical research has been provided for purpose of the article.

\section{RESULTS AND DISCUSSION}

\section{WATER DISTRICTS AND WATER BODIES}

In the territory of Slovenia we have two water districts: the Adriatic Sea water district and the Danube water district. The latter covers $81 \%$ of the national surface area, whereas a little less than a fifth of it belongs to the Adriatic Sea water district. These are also the actual water management districts. In the determination of surface water bodies, various factors are taken into consideration, such as transition of one category of water body to another (river, lake, transitional water, sea), changes in water type, or characteristic change in the environmental status of a water body.

The data on water bodies reflect the degree of present knowledge in the sphere of waters, and will be updated on the basis of new knowledge on typology, quality standards, and new data on their status. The division of Slovenia into ecoregions is made on the basis of distribution of various groups of water organisms. As only water organisms were taken into account, the term hydroecoregions was applied. For Slovenia, the following four hydroecoregions have thus been stipulated: the Po Plain, the Alps, the Dinarides, and the Pannonian Plain. In Slovenia, 22 types of running waters, 3 types of lakes and 2 types of sea were identified in 2005. Important special features of Slovenia are its karst waters which, however, are not specifically defined by the Water Framework Directive. In the first specification of running water types, the karst phenomena were taken into account as additional criteria for the arrangement in types.

In 72 Slovene rivers, 134 surface water bodies have been stipulated, 109 $(81.5 \%)$ of which fall within the Danubian water district and the remaining 25 
(18.5\%) to the Adriatic Sea water district. Each watercourse's independent water body includes all watercourses or their parts, with contributory areas smaller than $100 \mathrm{~km}^{2}$ that flow into this independent water body. Slovenia has three natural lakes (Bled, Bohinj and Cerknica) that meet criteria for the stipulation of independent water bodies and their arrangement in separate types. All three lakes are situated in the Danubian water district, where the only artificial water body of lakes, i.e. Lake Velenje, is also located. Owing to the various anthropogenic pressures associated with water use, 11 reservoirs have also been made on certain watercourses that are classified as candidates of heavily modified water bodies (HTWB). Altogether, 15 water bodies of lakes and artificial restraints of high water have thus been stipulated in Slovenia (Ministrstvo..., 2005a, b). Owing to the diverse pressures exerted on the sea by various anthropogenous activities, the Slovene sea has been divided into water bodies of the coastal sea, which enclose areas of one nautical mile from the coastline, and water body of the territorial sea. The Slovene sea is thus divided into six water bodies of the sea, in which the Škocjan Inlet has been included as well.

In the territory of Slovenia, 165 aquifer systems assembled in 21 water bodies of groundwater have been defined. In the Danube water district, 18 water bodies of ground water $(85 \%)$ have been established. Water bodies of groundwater differ a great deal in view of their size, considering that their surface areas range from 97 to $3,355 \mathrm{~km}^{2}$. The average surface area of a water body of ground waters of the Danube water district is $965 \mathrm{~km}^{2}$, whereas the surface areas of water bodies of ground waters of the Adriatic Sea are slightly larger.

\section{HYDROLOGICAL AND MORPHOLOGICAL PRESSURES TO WATER}

In the territory of Slovenia, altogether 31 larger dams have been documented. Uptake of water for various needs has been recorded on 86 water bodies. Much more water is uptake for the needs of small-scale hydroelectric power stations (almost 296) and breeding of water organisms (with 110 recorded fish ponds). In the Adriatic Sea water district, water is abstracted for the preparation of drinking water, in the Danube water district for the irrigation of arable land, preparation of drinking water and for the needs of various technological processes. On the basis of expert judgement it has been estimated that in view of the documented water uptakes and storages, hydrological pressures that have an impact on the status of surface water are present on 76 water bodies, i.e. on almost a half of all water bodies of surface waters (GLOBEVNIK et al., 2006). Smaller and less demanding water facilities and appliances, which individually do not exert significant pressures on the water regime, are not dealt with separately but within the framework of the arrangement of watercourses into classes in view of the state of the watercourses' 
morphological elements, which reflect the extent of hydro morphological pressures.

As morphological pressures exerted on lakes, anthropogenic pressures on the lakes' shores and particularly shores built up to more than $30 \%$ of their length were stipulated in the preparation of the first survey of morphological pressures. As far as natural lakes are concerned, only Lake Bled is defined as such, with 30 to $45 \%$ built up shore, and six lakes of anthropogenic origin with more than $45 \%$ built up shores.

\section{PRESSURES OF POLLUTION SOURCES TO WATER}

In Slovenia, 611 direct industrial discharges into watercourses have been recorded, 91 of which (15\% of all discharges) exceed the EPER threshold (the exceeding values are reported to the European Parliament Emission Register). A comparison between the two water districts show that direct industrial discharges in the Danube water district comprise 87\% (532 outflows) of all industrial discharges into Slovene watercourses and no less than 99\% (90) of all point pressures due to direct outflows of industrial wastewater into watercourses stipulated as significant. In Slovenia, there are also 53 cases of point sources of pollution from waste water treatment plants and 54 cases of pressures from agglomerations with unsuitable communal wastewater collection and treatment systems (48 of them located in the Danube water district (89\%)). Also significant, as point source pressures are concerned, are industrial plants or appliances with thermal pressures exerted on the national watercourses. There are 12 such industrial plants or appliances in the Danube water district, while in the Adriatic Sea water district no such pressures have been recorded.

Diffuse sources of pollution play an important part as point sources from the aspect of input of plant nutrients, pesticides and other forms of pollution on entire catchment areas. Within the framework of the first review of pressures exerted waters from diffuse pollution sources, a survey of pressures with nitrogen and phosphorus in agriculture was prepared. The survey is based on the overall analysis of the agricultural activities in Slovenia, on which evaluation of the nitrogen and phosphorus balance for fields, vineyards, grasslands; orchards and heterogeneous agriculture land have been calculated. The next step in a process of WFD implementation in Slovenia will be to model the fate of calculated surpluses of pollutants that is how much of nitrogen and phosphorus surpluses reach surface and ground waters. 


\section{AGRICULTURAL ACTIVITIES IN SLOVENIA}

Approximately one third of Slovene surface area, which measures $20.250 \mathrm{~km}^{2}$ belongs to the agricultural area, what covers app. 618.000 ha. Arable land (34.8\%) and extensive meadows (30.6\%) prevail among different use of agricultural land. Meadows together with pastures represent grassland and cover $50 \%$ of agricultural land in Slovenia. Animal breading is the main farm production in Slovenia and cattle breading is prevailed with the share of $70 \%$. The animal density per hectare in Slovenia is only slightly above the average animal density in EU, what is 0.92 and $0.90 \mathrm{LSU} \cdot \mathrm{ha}^{-1}$ respectively. LSU is "livestock size unit" what corresponds $500 \mathrm{~kg}$ of weight of an animal. Animal density over $1.5 \mathrm{LSU} \cdot \mathrm{ha}^{-1}$ of agricultural land could be observed in the central north and in some areas toward to the east part of Slovenia. The lowest animal density is on the east, west and south part of Slovenia. National statistical data show that fertilizer consumption has slightly decreased since the year 1999 (Figure 1). As almost all over Europe, agricultural area is decreasing due to urbanization in Slovenia as well, and due to natural afforestation what is a phenomenon in some European countries only. Considered only fields, orchards, vineyards, and intensive meadows as fertilised area, the amount of plant nutrients applied per hectare has increased in last ten years, but shows a certain level of stabilisation in last few years (Figure 2).

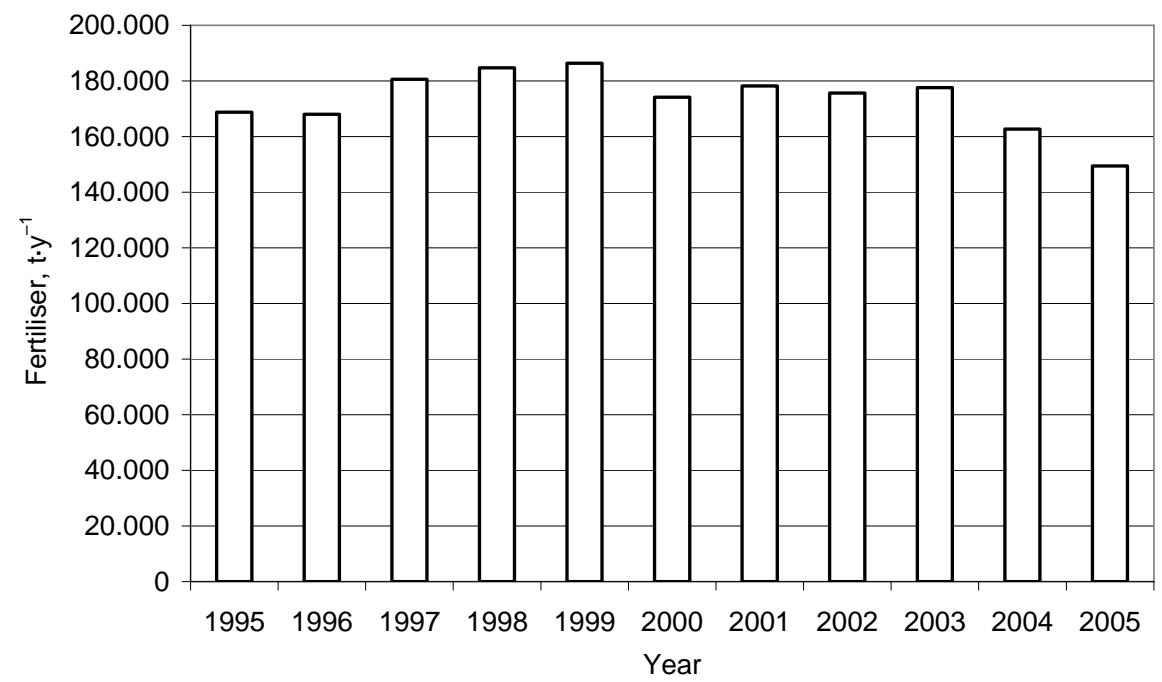

Fig. 1. Consumption of mineral fertilizers in Slovenia in the years 1995-2005

(Statistical Office of Republic of Slovenia, 2007) 




Fig. 2. Fertilized area (ha) and consumption of plant nutrients in Slovenia in the years 1995-2005

(Statistical Office of Republic of Slovenia, 2007)

\section{CALCULATION OF NITROGEN AND PHOSPHORUS BALANCE}

Nitrogen balance for field, vineyard, grassland, orchard and heterogeneous agriculture land has been calculated based input and output parameters. Input parameters: a) consumption of $\mathrm{N}$ mineral fertilizers in $\mathrm{kg} \cdot \mathrm{ha}^{-1} \cdot \mathrm{year}^{-1} \mathrm{a}$ and b) livestock manure from number of pigs, chicken and cattle on fields and grasslands) have been defined from statistical data from 2000. Other input parameters, c) nitrogen from precipitation, d) humus mineralisation and c) biological fixation from $\mathrm{Fa}$ baceae for grassland have been predefined. Outputs calculated are nitrogen crop uptake and denitrification. Land use data have been gethered from Corine land Cover 2000 (CLC, 2000).

Nitrogen balance for each agriculture landuse has been calculated as a difference between inputs and outputs. The balance has been calculated as a weighted average for second level hydrogeographical areas in Slovenia. The highest surplus (more that $120 \mathrm{~kg} \mathrm{~N} \cdot \mathrm{ha}^{-1} \cdot \mathrm{year}^{-1}$ ) appears toward the east of Slovenia, meanwhile the lowest surplus of nitrogen (less than $80 \mathrm{~kg} \mathrm{~N} \cdot \mathrm{ha}^{-1} \cdot \mathrm{year}^{-1}$ ) appears toward the west part of Slovenia (Figure 3). Phosphorus balance for field, vineyard, grassland, orchard and heterogeneous agriculture land use has been calculated based on the inputs and output parameters. The input parameters are: consumption of $\mathrm{P}_{2} \mathrm{O}_{5}$ mineral fertilizers $\left(\mathrm{kg} \cdot \mathrm{ha}^{-1} \cdot \mathrm{year}^{-1}\right)$ (from statistical data for the year 2000), b) livestock 


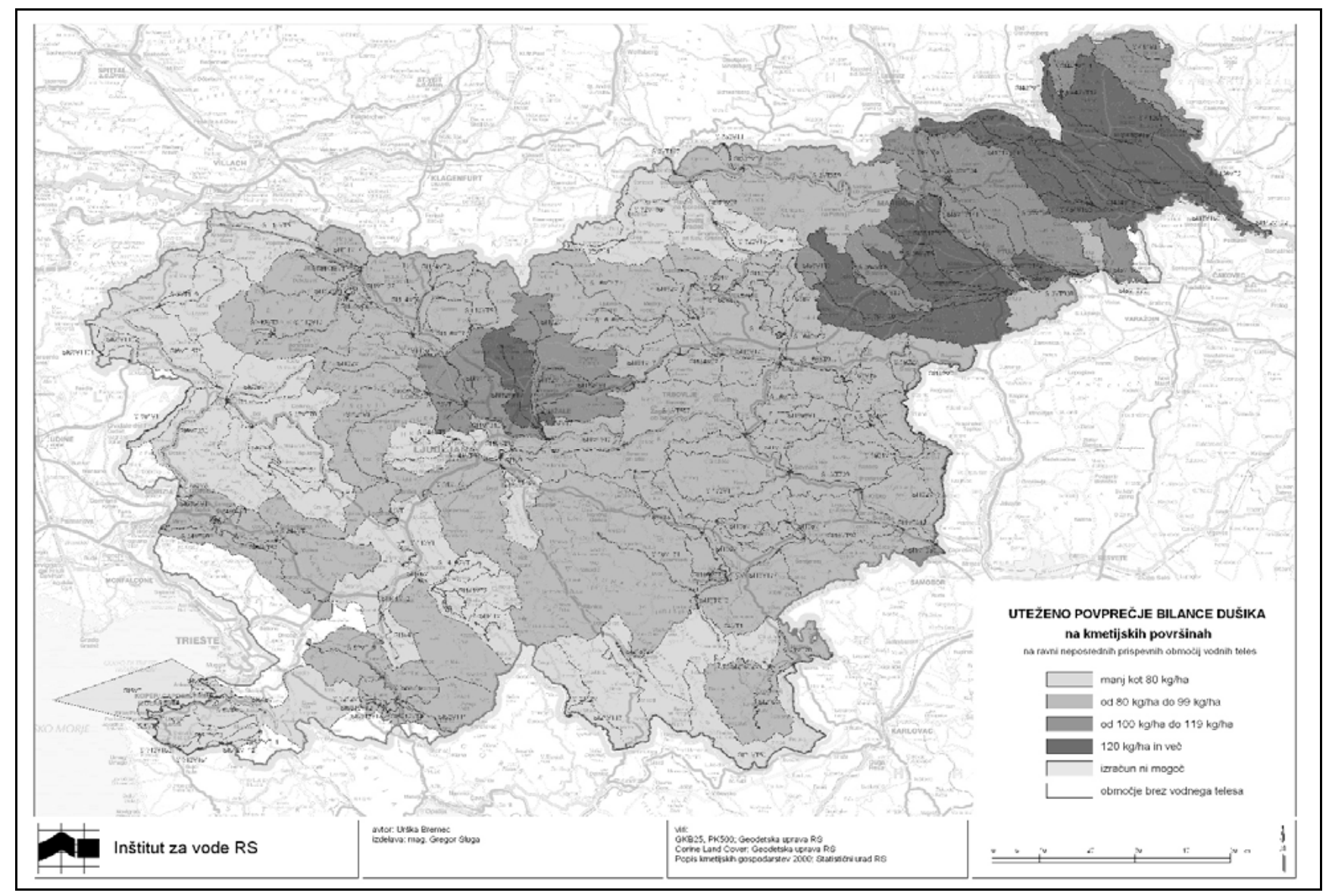

Fig. 3. Weighted average nitrogen balance $\left(\mathrm{kg} \mathrm{N} \cdot \mathrm{ha}^{-1} \cdot \mathrm{year}^{-1}\right)$ for the surface water bodies contributory areas (legend, upside down: $<80 \mathrm{~kg} \cdot \mathrm{ha}^{-1} ; 80-99 \mathrm{~kg} \cdot \mathrm{ha}^{-1} ; 100-119 \mathrm{~kg} \cdot \mathrm{ha}^{-1} ;>120 \mathrm{~kg} \cdot \mathrm{ha}^{-1}$; calculation not possible; area without surface waters) 
manure from number of pigs, chicken and cattle on field and grassland (from statistical data for the year 2000) and c) phosphorus from precipitation (predefined values). The output parameter is phosphorus crop uptake. The procedure for phosphorus balance calculation has been the same as for the nitrogen. The Figure 4 shows the weighted average of phosphorus balance $\left(\mathrm{kg} \mathrm{P} \cdot \mathrm{ha}^{-1} \cdot \mathrm{year}^{-1}\right)$ for contributory area of each surface water body. The pattern of surpluses is almost the same for both pollutants. The highest surplus (more that $10 \mathrm{~kg} \mathrm{P} \cdot \mathrm{ha}^{-1} \cdot \mathrm{year}^{-1}$ ) appears more toward the east of Slovenia, meanwhile the lowest surplus appears toward the west part of Slovenia.

\section{ASSESSMENT OF THE PRESSURES IMPACT ON THE WATER BODIES STATUS}

The status of waters in Slovenia is assessed in view of the environmental objectives stipulated by the Water Framework Directive. These objectives are defined as "good chemical" and "good ecological" status for the water bodies of surface waters and "good chemical" and "good quantitative" status for the water bodies of groundwater. In order to establish whether separate water bodies are going to reach the environmental objectives, a scale of four descriptive marks in view of the probability of achieving these objectives has been made:

- environmental objectives will be achieved

- environmental objectives may be achieved

- environmental objectives may not be achieved

- environmental objectives will not be achieved

The first and fourth marks are used when suitable and reliable data on the status of water bodies are at hand or when it can be claimed with certainty that there is a very small or very big impact of pressures on a water body. In the opposite cases, the second and third descriptive marks are used.

\section{SURFACE WATER BODIES}

The assessment whether surface water body will attain certain environmental objectives as stipulated for them is initially made separately in view of hydrological, morphological, chemical and biological elements as well as with regard to pressures exerted in direct contributory areas of separate water bodies. Final assessment for the bodies where measurements do exist is the worst among status assessments. The results are shown in the Figure 5. A fourth of water bodies of Slovene watercourses will not attain their environmental objectives, whereas for only a good eighth of them it is estimated that good status will be attained. For more than half of the water bodies of watercourses it has been estimated that they will (probably) not reach the Directive's environmental objectives. The conditions 


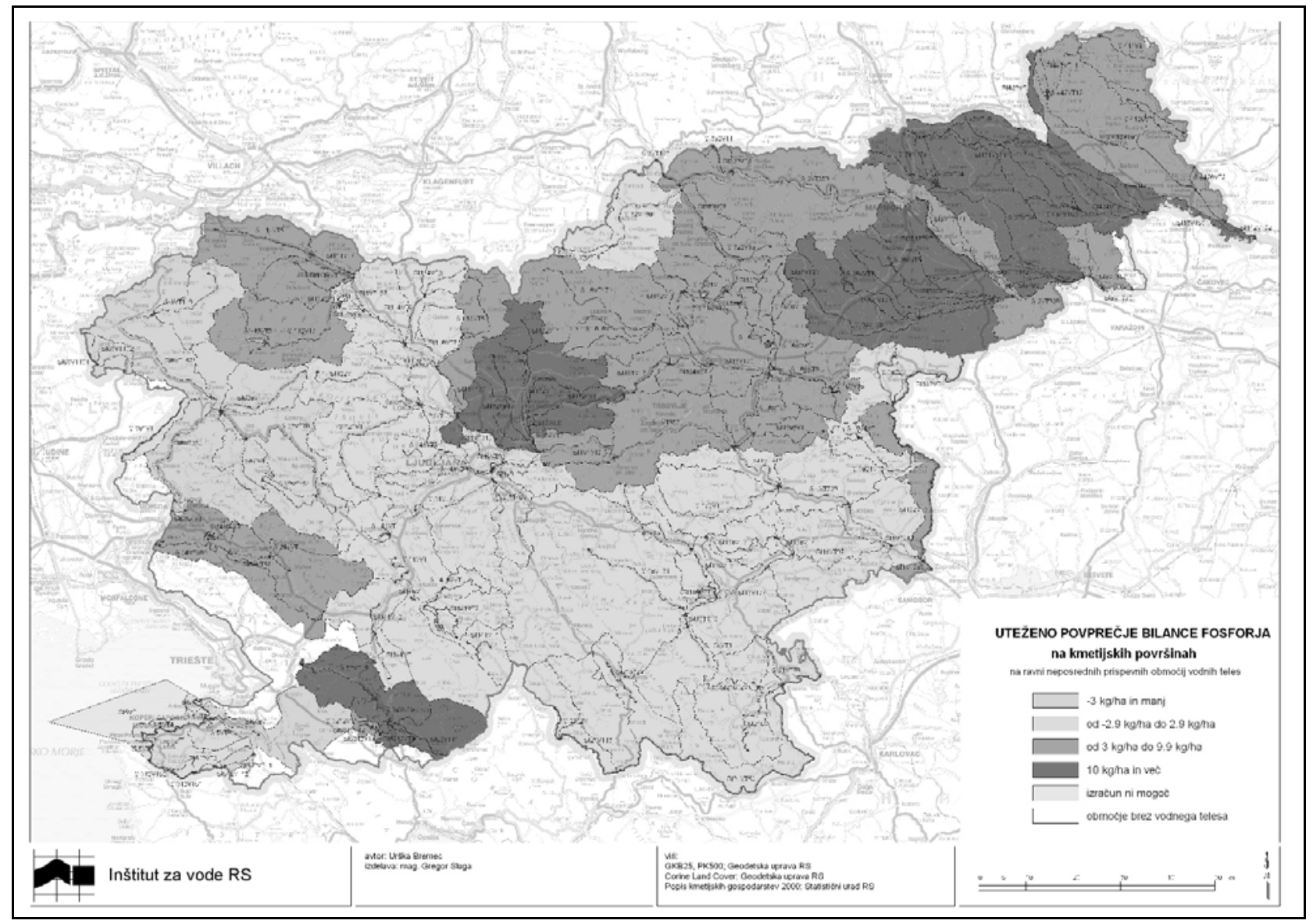

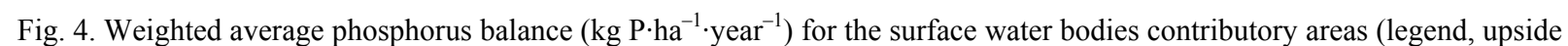
down: $<(-3) \mathrm{kg} \cdot \mathrm{ha}^{-1} ;(-2.9)-2.9 \mathrm{~kg} \cdot \mathrm{ha}^{-1} ; 3-9.9 \mathrm{~kg} \cdot \mathrm{ha}^{-1} ;>10 \mathrm{~kg} \cdot \mathrm{ha}^{-1}$; calculation not possible; area without surface waters) 


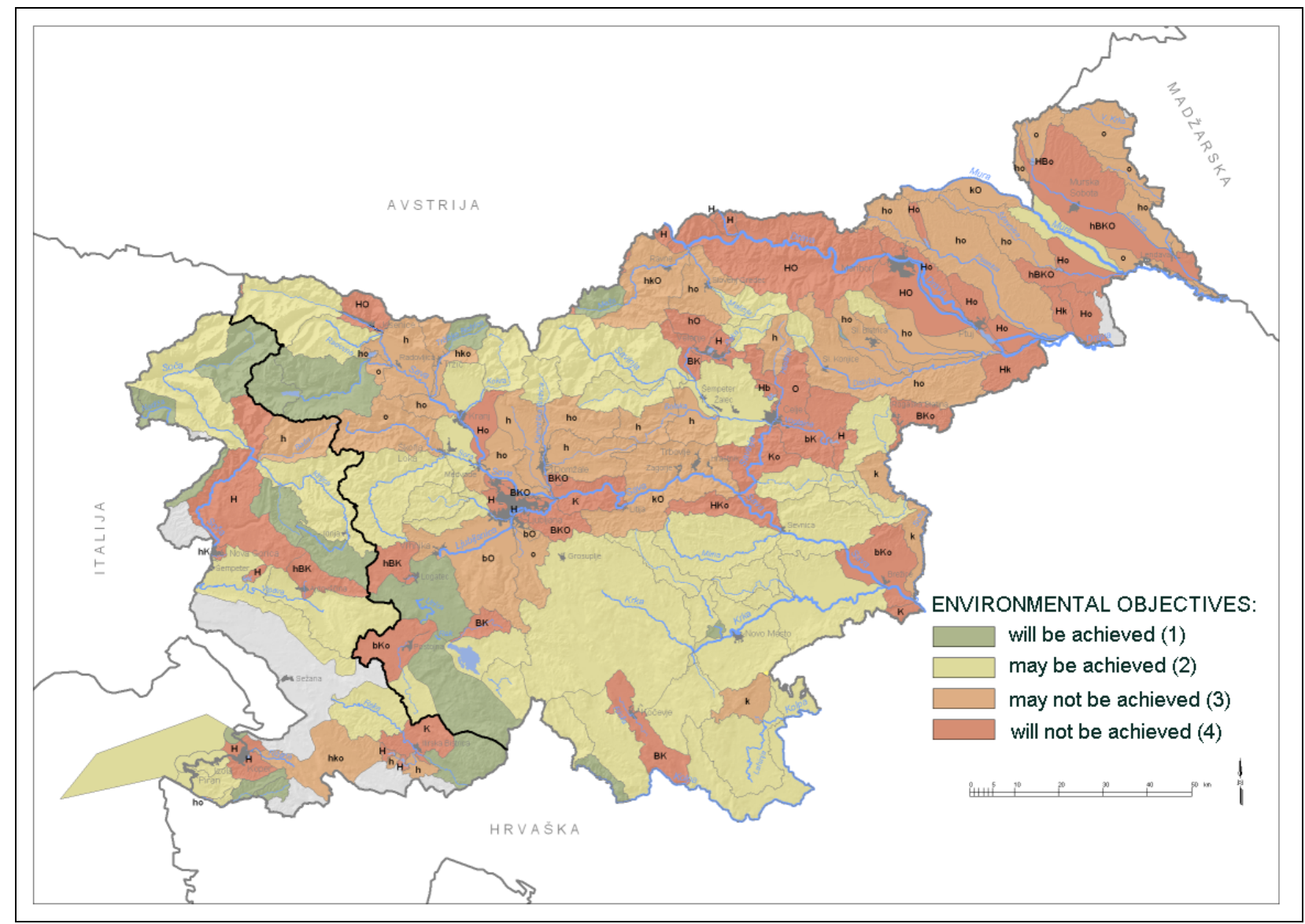

Fig. 5. The probability of achieving environmental objectives, shown for direct contributory areas of the surface water bodies. Red and orange indicate that environmental objectives will not or may not be achieved (adapted from GLOBEVNIK, 2006) 
are clearly most critical in the north eastern part of Slovenia, where water bodies that will (probably) not attain the environmental objectives prevail, while in the western and southern parts of the country the environmental status is estimated, with few exceptions, as a great deal more favourable.

\section{GROUND WATER BODIES}

In all water bodies of the Slovene groundwater, a balance between the used and disposable quantities of groundwater has been restored, which means that the impacts of major pressures on their quantitative status are under control. But data on water quality indicate excessive pollution of the "Drava", "Savinja" and "Mura" ground water bodies. Those are classified as being at risk (Figure 6). Groundwater pollution is primarily the result of pressures originating from dispersed sources of pollution, which is particularly explicit in the very north eastern part of Slovenia. The most critical chemical parameters are desethilatrazin, nitrates and atrazin. While the trends of atrazin and desethilatrazin contents are mostly falling, the trends of nitrate contents are more worrying considering that in some places they are still rising (Ministrstvo..., 2005a, b).

\section{NITRATE DIRECTIVE}

According to the Nitrate Directive (Directive of European Council 91/676/EEC) the whole territory of Slovenia has been designated as a vulnerable zone with the amendment of the "Regulation on the Input of the Dangerous Substances and Plant Nutrients into the Soil" (Official Journal RS 35/2001). The Nitrate Directive has been transposed into the national regulative.

The action program for protection of waters against nitrate pollution from agricultural sources for the period 2004-2008 has been prepared based on the "Environment Protection Law" (Official Journal RS 32/93; 1/96) and National Program of the Environment Protection. The program includes three groups of measures applied to the whole territory:

- Measures for fertilizer application according to the principles of good agricultural practices and for taking account of limit values for annual applications.

- Measures to ensure appropriate storage capacities for livestock manure.

- Measures for adopting livestock operations to environmental standards (There are 25 bigger livestock operation in Slovenia that cause substantial environmental problems).

- Measures for reasonable fertilizer application are as follows:

Threshold value for annual input of nitrogen in livestock manure is 170 $\mathrm{kg} \cdot \mathrm{ha}^{-1} \cdot \mathrm{year}^{-1}$. Periods of prohibited liquid manure application: from $15^{\text {th }}$ of Nov. 


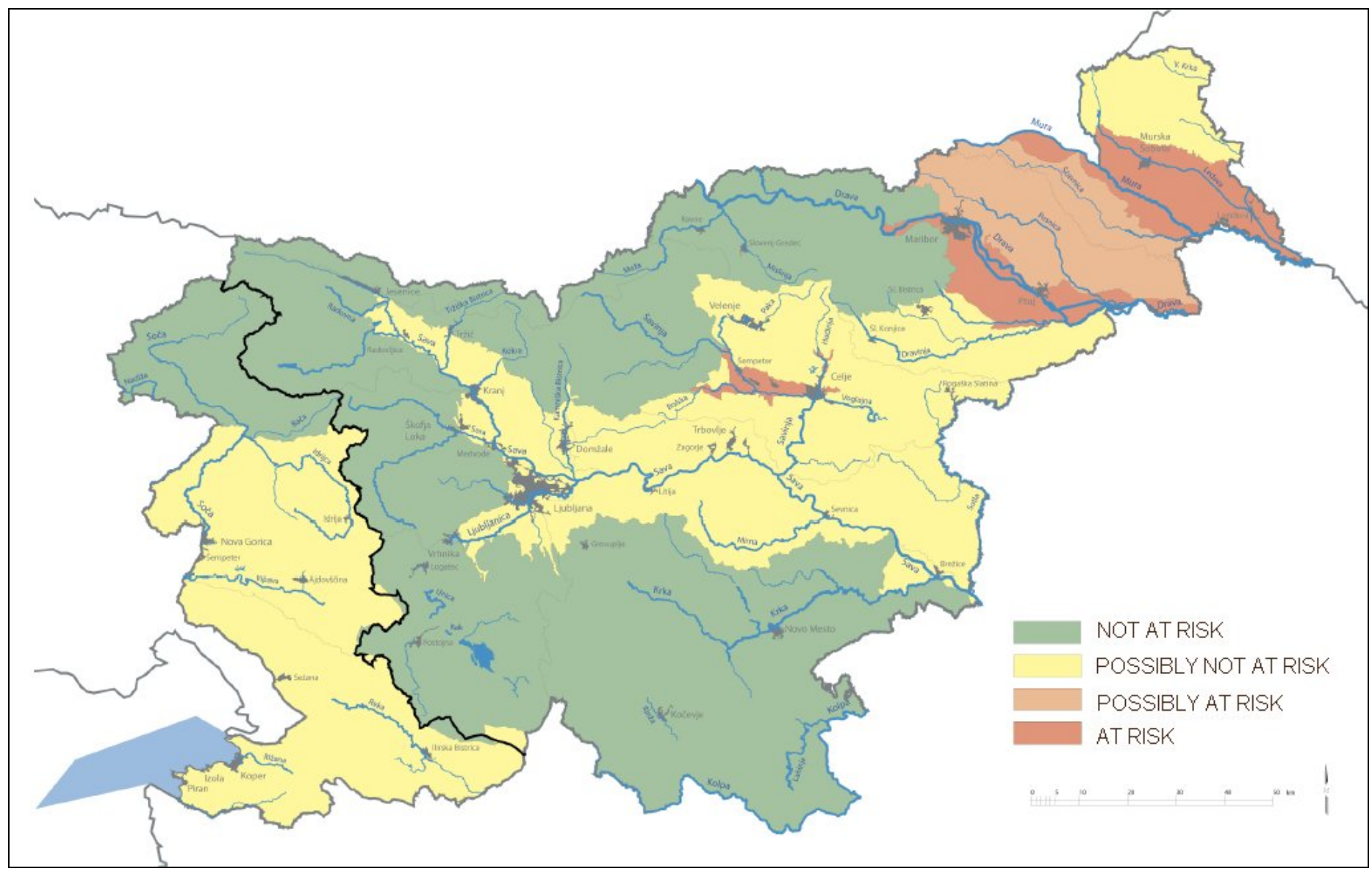

Fig. 6. Assessment of attaining good status for Slovene ground water bodies (adapted from GLOBEVNIK, 2006) 
till $15^{\text {th }}$ of Feb. Restricted use of manure on steep slopes, water-saturated ground, and on frozen or snow-covered ground, on aquatic and coastal land and in flood zones. Some special measures are prescribed in water protection zones

Prohibition of use of any kind of manure or fertilizer on water areas, which are represented by strips along watercourses in a width of $15 \mathrm{~m}$ at rivers of the $1^{\text {st }}$ order and of $5 \mathrm{~m}$ of the other. Plans for fertilization on a farm level taking into account the status of fertilizer in a soil profile. Storage capacities for livestock manure should be adequate for the period of storage, when application of manure is not permitted and additionally for periods when the weather conditions do not permit fertilizer application

\section{CONCLUSIONS}

The first pressure and impact analyses and water status assessment of Slovenian water show that hydromorphological and chemical pressures (point pressures exerted on water bodies by industry) are the main reasons for the non-attainment of environmental objectives, quite often in connection with diffuse pollution from agriculture and various urban agglomerations. This is particularly characteristic of the northeastern part of Slovenia, the entire course of the Drava River and the Sava River's water bodies in its middle and lower parts.

Not favourable environmental status of the water in the northeastern part of Slovenia corresponds with results of nitrogen and phosphorus balance in Slovenia. It has been calculated that the highest nitrogen surplus $\left(>120 \mathrm{~kg} \mathrm{~N} \cdot \mathrm{ha}^{-1} \cdot \mathrm{year}^{-1}\right)$ and the highest phosphorus surplus $\left(>10 \mathrm{~kg} \mathrm{P} \cdot \mathrm{ha}^{-1} \cdot \mathrm{year}^{-1}\right)$ appears toward the east of Slovenia.

Though consumption of mineral fertilizers and plant nutrients in Slovenia have decreased 1995 since and reached more or less steady state in the last years, an assessment of water environment status showed the quantities are still too high to reduce the risk to water environment. The measures for reasonable fertilizer applications being implemented in Slovenia on the basis of Nitrate Directive are quite strict, but still too general to be efficiently introduced into practice. On the other hand there is hardly any efficient control mechanism developed. Therefore, the measures for reasonable fertilizer applications should be developed into more details as to give more directions for a farm level management. Miscellaneous instruments should also be developed to initiate overall sustainable use of fertilizers and plant nutrients in agriculture to reduce risk to water environment such are financial incentives, awareness and knowledge rising actions, educations, etc. 


\section{REFERENCES}

1. Navodilo za izvajanje dobre kmetijske prakse (Code of good agricultural practice), 2000. OJ RS 34 .

2. Corine land cover, 2000. Geodetska uprava Republike Slovenije, Ljubljana, 2003.

3. Environment protection Law (Zakon o varstvu okolja), 1993, 1996. OJ RS 32/93 and 1/96.

4. GlobevniK L., 2006. Izvajanje Vodne direktive v Sloveniji: predstavitev prvih ocen možnosti doseganja okoljskih ciljev za vodna telesa v Sloveniji po načelih Vodne direktive. Inštitut za vode Republike Slovenije.

5. Globevnik L, Bizjak A., Bremec U., Dodoč J., Drev D., Gabrijelčič E., Peterlin M., Sluga M., SMOLAR ŽVANUT N., URBANIČ G., 2006. Strokovne podlage za začasni načrt upravljanja voda. Inštitut za vode Republike Slovenije.

6. Ministrstvo za okolje in prostor, 2005a. Izvajanje Vodne direktive na Vodnem območju Jadranskega morja, Ljubljana. Ministrstvo za okolje in prostor.

7. Ministrstvo za okolje in prostor, 2005b. Izvajanje Vodne direktive na Vodnem območju Donave, Ljubljana Ministrstvo za okolje in prostor.

8. Regulation on the input of the dangerous substances and plant nutrients into the soil (Uredba o spremembah in dopolnitvah uredbe o vnosu nevarnih snovi in rastlinskih hranil v tla), 1996, 2001, 2004. OJ RS 68/1996, 35/2001, 29/2004.

9. Statistični urad Republike Slovenije, 2007. Statistical data.

\section{SUMMARY}

\section{Harmonizowanie gospodarki wodnej i polityki rolnej w Słowenii}

Słowa kluczowe: czesści wód, Dyrektywa Azotanowa, gospodarka wodna, polityka rolna, Ramowa Dyrektywa Wodna

Człowiek odczuwa rosnącą potrzebę zrozumienia związków między użytkowaniem zlewni i jakością wód rzecznych, aby zachować lub poprawić tę jakość. W trosce o ilościowy i jakościowy status wód Unia Europejska przyjęła Ramową Dyrektywę Wodną (2000/60/EU). Proces analizy oddziaływania gospodarki, w tym rolnictwa, na stan jakościowy wód nazwano w skrócie "pierwszą charakterystyką" scalonych części wód. Zgodnie z RDW, programy służących temu narzędzi mają powstać do roku 2009. W programach RDW stworzone zostaną nowe środki ochrony wód, a istniejące, takie jak europejska Dyrektywa Azotanowa, Dyrektywa o gospodarce odpadami i substancjami niebezpiecznymi oraz IPPC, będa rozwijane. W artykule przedstawiono wstępną charakterystykę słoweńskich wód i wzajemną zgodność Dyrektywy Azotanowej i Ramowej Dyrektywy Wodnej w Słowenii.

Reviewers:

Prof. Edmund Kaca

Prof. Edward Pierzgalski 